\title{
Improvement of aquifer transmissivity assessment in crystalline and metamorphic fractured rocks in Bondoukou area, North-Eastern Côte d'Ivoire.
}

\author{
T. Lasm ${ }^{\star 1}$, M. Youan T.A ${ }^{1,2}$, D. Baka1, Z.O. D.E Lasme', M.S. Oga ${ }^{1}$, P. Jourda ${ }^{1,2}$, \\ J. Biemi ${ }^{1}$
}

${ }^{1}$ Laboratory of Sciences and Techniques of Water and Environment Engineering, Department of Earth Sciences and Mining Resource (UFR-STRM), University of Cocody, 22 BP 582

Abidjan 22 (Côte d'Ivoire), Tel: +225 22483838 , Fax: 22522445270.

${ }^{2}$ University Research Center of Remote Sensing and Application (CURAT), University of Cocody, 22 BP 801 Abidjan 22 (Côte d'Ivoire), Tel/Fax: + 22522445270.

*Corresponding author. E-mail: theophile_lasm@yahoo.fr/ theophile.lasm@gmail.com

\begin{abstract}
This study is performed in the Bondoukou area located in north-eastern Côte d'Ivoire. The aim of this study was to improve the assessment of transmissivity of the highly fractured aquifers of Bondoukou area using kriging techniques. A previous estimation of the transmissivity was conducted with aquifer transmissivity of crystalline rocks $(n=62)$. These transmissivities were later supplemented by 78 samples of aquifer transmissivity of metamorphic rocks. The results of this study were compared with those obtained in crystalline rock aquifers. In both cases, the variogram exhibits a large nugget effect representing respectively 63 and $70 \%$ of total dispersion. The nugget effect of this study is less important than the previous study. The range is equal to 12 $\mathrm{km}$ and is larger than that obtained in the previous study. The structuring of the variogram is enhanced when we consider the aquifer transmissivity of metamorphic rocks. Transmissivity estimated in both studies varies between 4.00E-06 and $1.72 \mathrm{E}-06 \mathrm{E}-05 \mathrm{~m}^{2} . \mathrm{s}^{-1}$ and between 3.86 $\mathrm{E}-06$ and $1.84 \mathrm{E}-05 \mathrm{~m}^{2} . \mathrm{s}^{-1}$ respectively in the previous study and in this study. In both cases, the observed and estimated transmissivities values are comparable and are spread over two orders of magnitude. Kriging maps showed that the estimation of transmissivity in Bondoukou area is better in this study. The results obtained in this study are interesting because they showed improved estimate of the transmisssivity in the Bondoukou area.
\end{abstract}

Key-words: crystalline basement, fractured aquifers, Bondoukou, transmissivity, variogram, kriging.

\section{INTRODUCTION}

In Côte d'Ivoire, the basement occupies the majority of the territory, over $97.5 \%$ of the territory. This basement consists of crystalline and metamorphic rocks, which are fractured by different tectonic events (Camil, 1984; Kouamelan, 1996; Djro, 1998). Rocks deformations led to the development of fractures. In this country, groundwater is constituted of water from sedimentary and hard rocks reservoirs. The bulk of groundwaters are contained in aquifers formed by fractured basement. Groundwater resources management and optimal exploitation require an accurate knowledge of hydraulic properties of aquifers, which controls the groundwater flows (Painter et al., 2007; Onetié et al., 2010). Obtaining reliable hydrological input parameters is one of the key challenges in groundwater modelling applications. Transmissivity is a major hydraulic parameter of aquifers and is evaluated using pumping tests (Mace et al., 1999; Razack and Lasm, 2006; Gupta, 1989; Kawecki, 1993, 1995, Helweg, 1994). However, available pumping tests are often few, which does not allow analysing and assessing the distribution of this important parameter on large areas using classical methods. Transmissivity is a 
Am. J. Sci. Ind. Res., 2012, 3(5): 315-330

highly variable parameter, it often varies dramatically and exhibits large fluctuations. It is rarely feasible to obtain enough measurements to fully characterize an aquifer (Painter et al., 2007; Boucher et al., 2009). This variability in space can be explained by the fact that the aquifers are often heterogeneous.

The use of geostatistical techniques allow the estimation of this parameter on the entire study domain with a better accuracy (Razack and Lasm, 2006; Lasm et al., 2008; Baka et al., 2011). During the last decades, several studies (Ahmed and De Marsily, 1987, 1993; Fabbri, 1997; De Marsily et al., 1999; Razack and Lasm, 2006; Lasm et al., 2008) have been carried out in geostatistical analysis of aquifers hydraulic parameters such as transmissivity and permeability. The different findings have shown that the geostatistical approach can lead to a reliable estimation of the transmissivity. In Côte d'Ivoire, the study of the transmissivity has been performed by many authors (Faillat, 1986a et b; Soro, 1987; Biémi, 1992; Savané, 1997; Savané et al., 1997). Unfortunately these studies are limited to statistical description. There are very few works (Lasm, 2000; Razack and Lasm, 2006; Lasm et al., 2008; Lasm et al., 2009) concerning geostatistical estimation of fractured crystalline and metamorphic aquifers parameters. Techniques to estimate transmissivity data have been successfully applied in many aquifers in Côte d'Ivoire by Lasm (2000), Razack and Lasm (2006) and Lasm et al. (2008) and elsewhere to provide valuable information for inputting in numerical models and for evaluating water resources.

The work presented here, concerns an area located in north-eastern Côte d'Ivoire (Bondoukou) where fracturing is developed and boreholes available for drinking water supply are quite few. This study aims at improving the transmissivity assessment of crystalline and metamorphic fractured aquifers based on a geostatistical approach. The findings will contribute to a better hydrogeological knowledge of these fractured aquifers in order to implement optimal exploitation of their water resources.

Study area: The study area is located in the northeastern part of Côte d'Ivoire between the latitudes $7^{\circ} 55^{\prime}$ and $8^{\circ} 30^{\prime}$ north and longitudes $2^{\circ} 40^{\prime}$ and $3^{\circ} 20^{\prime}$ west and covers a surface of $4225 \mathrm{~km}^{2}$ (figure 1).

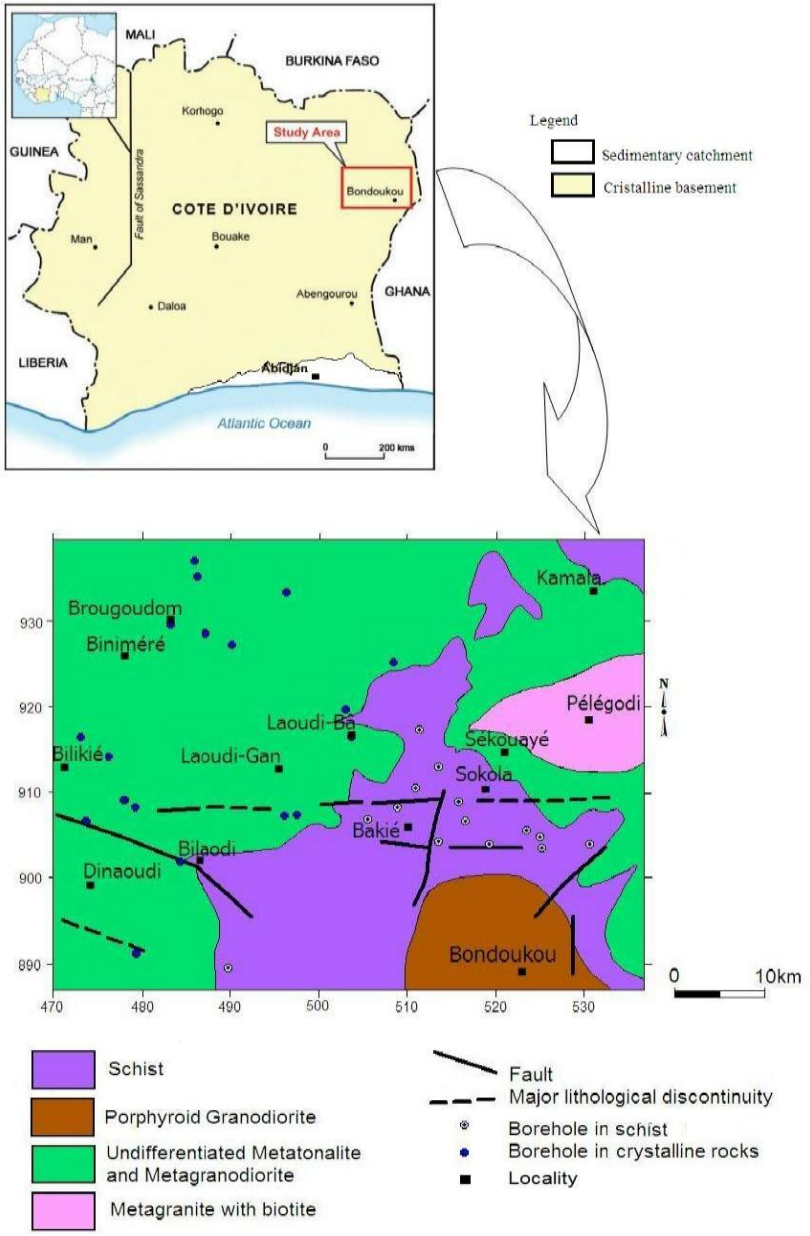

Fig. 1: Location and geological map of the study area with distribution of the boreholes.

Bondoukou area includes two main rivers: the Comoé river to the South-East and the Black Volta river to the North-West. The hydrographic network of this area is dense. The drainage network is associated to the faults network (La Barbera and Rosso, 1989; Phillips, 1993; Lasm and Razack, 2001), i.e. the rivers flow principally in the faults network.

In this area, the first hydrogeological studies are the works of Lasm et al. (2008) and Youan Ta (2008) which constitutes important findings in the knowledge of aquifer transmissivity in this area. The assessment of this hydraulic parameter over the whole area proves that it is important to understand the groundwater flow and projected modelling tasks.

In Bondoukou area the failure rate of hydrogeology prospecting is very low, this rate is about $20 \%$. This result can be explained by the prospecting approach 
used in the rural hydraulic program, where boreholes are carried out based on geomorphologic considerations (Faillat, 1986a; Biémi, 1992; Lasm 2000). The geophysical methods are only used when the failure rate is important (>50\%) (Faillat, 1986a; Biémi, 1992).

The population of Bondoukou area is estimated at about 372000 inhabitants. This population is very unequally distributed. Indeed, more than $70 \%$ of this population is concentrated in the city of Bondoukou and around other localities (Bondo-Dioula, LouadiBâ, Yézimala). The water management agency (Direction de l'Eau) estimated that only about $58 \%$ of the water requirements for the city of Bondoukou and its satellite villages were satisfied. These observations show that new boreholes are necessary to cover all water supplies. In dry season, surface waters and sub surface water dry up and fresh waters is very rare. Therefore, groundwater constitutes the main water resource supply for drinking in this part of Côte d'Ivoire. This groundwater is fresh water with good quality. Groundwaters of Bondoukou are characterized by low or little concentration of Total Dissolved Solids (88 to 772 $\mathrm{mg} \cdot \mathrm{L}^{-1}$ ), electric conductivity contained between 134 and $652 \mu \mathrm{s} . \mathrm{cm}^{-1}$ with temperature's average measured at $26.3^{\circ} \mathrm{C}$ (Youan Ta, 2008).

The major fault of Sassandra divides the crystalline basement of Côte d'Ivoire in two principal geological domains: the archean domain in the western part and proterozoic domain in the eastern part. These two domains occupy about $97.5 \%$ of Côte d'Ivoire and the remaining $2.5 \%$ of the land is occupied by the sedimentary coastal catchment. Bondoukou area is a part of the proterozoic domain of Côte d'lvoire. Regarding geological aspects, proterozoic domain comprises a set of gneisses, constituting the basement of supracrustal formations which have volcanic, sub-volcanic and sedimentary origin, deposited in furrows or intracratonic basins in which the granites of the Eburnean cycle took place (Kouamelan, 1996). These formations were differentiated from the mantle between 2200 and $2300 \mathrm{Ma}$ and characterize the Birimian. In Bondoukou area, three lithological units can be distinguished (figure 1): i) schist unit, constituted of several different petrographic sub-units, outcroping in the southern and the central part of the sector; ii) an intrusive unit consisted primarily of granodiorite more or less metamorphized and secondarily of granites and tonalites; iii) a tarkwaian unit constituted of post- tectonical detritical formations represented by conglomerates, sandstones and arkoses.

The works of Jourda (2005), Youan Ta (2008), Youan $\mathrm{Ta}$ et al. (2008) and Youan Ta et al., (2011) have shown that the Bondoukou area is intensely fractured and includes thousands of fractures with variable sizes. They performed a critical and synthetic study of the fracturing of this area. The second and third studies point out many fractures of regional size (30 to $80 \mathrm{~km}$ ) which where unknown by previous studies (Youan Ta et al., 2008). The findings of these authors contributed to update fractures mapping of the Bondoukou area. The fracturing data comes from the interpretation of satellite images of ETM+ Landsat, aerial photos and geological field surveys. The directional histogram analysis shows that fracturing in the Bondoukou area is almost homogeneous, indeed major fracture directions are not clearly identified (figure 2). The distribution frequencies of the family of fractures spread between 2.25 and $9.7 \%$. Tectonics of this area is polyphased and quite complex compare to the other fractured provinces of the country (Zeade et al., 1995; Delor et al., 1995).

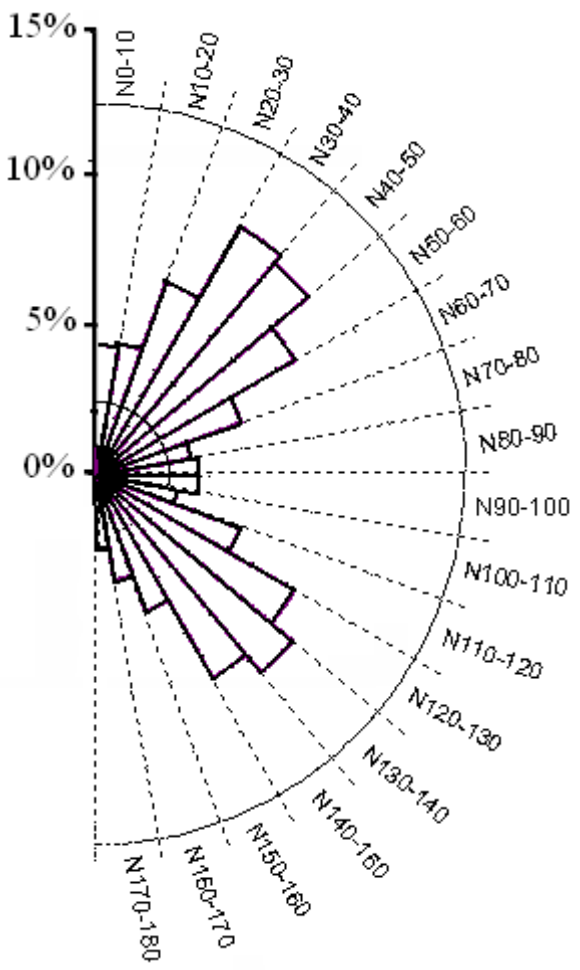

Fig. 2: Orientation distribution expressed in relative frequency of the fracture networks 
Data and methods:

Data: Data available for this study come from pumping tests performed on isolated boreholes. The boreholes were drilled in crystalline and metamorphic fractured hard rocks (figure 1). A critical and synthetic study of hydrogeology of the fractured crystalline basement aquifers was recently performed by Lasm et al. (2008) and Youan Ta (2008). In the study area, crystalline rocks occupy the most geographical distribution (more than $2 / 3$ of the total area) and schist formations occupy $1 / 3$ of this area. Therefore numerous boreholes are drilled in the crystalline rocks and so very few in schist rocks. It is the main reason why a previous study was performed by Lasm et al. (2008) concerning transmissivity assessment on solely crystalline rocks using 62 data points of transmissivity to characterize this formation.

This study incorporates all available data of transmissivity in Bondoukou area i.e. in crystalline and metamorphic rocks. All boreholes tap the fractured aquifers of which 62 and 16 respectively in the crystalline rocks and metamorphic rocks.

Transmissivity values were determined from the interpretation of pumping tests data using the recovery test data and Theis recovery method (Theis, 1935) in order to eliminate the effect of turbulent head losses in the borehole and gravel pack (Razack and Lasm, 2006; Lasm et al., 2008). Drawdowns were measured directly in pumping well. The pumping test is a step drawdown test with generally three steps lasting from 4 to 12 hours and 2 to 4 hours of recovery. The pumping tests lasting less than $12 \mathrm{~h}$ were not kept.

The boreholes are distributed on a surface of 4225 $\mathrm{km}^{2}(65 \mathrm{~km} \times 65 \mathrm{~km})$ (figure 1). Boreholes studied in this work don't all on the geological map (figure 1) because of study area size and the scale used. Indeed, several boreholes in the villages are confounded in one point on the map. It's the example of Bilekie, Biraodi, Brougoudom, Dovagne, Kuafo, Sekouaye and Soko Sorobango villages. It is the reason why the number of boreholes is reduced on the geological map.

Boreholes distribution over the area is not homogeneous. Indeed, boreholes don't cover the totality of the study area, the south part of study area includes very few data; the north, centre and east parts have the majority of data.

In crystalline rocks, transmissivity oscillates between $1.08 \mathrm{E}-06 \mathrm{~m}^{2} . \mathrm{s}^{-1}$ and $5.36 \mathrm{E}-05 \mathrm{~m}^{2} . \mathrm{s}^{-1}$ with an average of $1.21 \mathrm{E}-05 \mathrm{~m}^{2} . \mathrm{s}^{-1}$ while in metamorphic rocks, it spreads between $2.97 \mathrm{E}-06 \mathrm{~m}^{2} . \mathrm{s}^{-1}$ and $1.68 \mathrm{E}-05 \mathrm{~m}^{2} . \mathrm{s}^{-}$ with an average of $8.56 \mathrm{E}-06 \mathrm{~m}^{2} \cdot \mathrm{s}^{-1}$. The transmissivity data on the study area oscillate therefore between 1.08E-06 m $\mathrm{m}^{2} . \mathrm{s}^{-1}$ and 5.36E-05 $\mathrm{m}^{2} . \mathrm{s}^{-1}$, span two orders of magnitude, and reflect the heterogeneity of these aquifers. This finding is in agreement with the works performed in basement of Côte d'Ivoire and West Africa (Faillat and Leblond, 1982; Faillat, 1986 a and b; Biémi, 1992; Lasm, 2000; Jourda, 2005; Lasm et al., 2004; Razack and Lasm, 2006). The summary statistics is given in table 1 and the frequency distribution of raw transmissivity $(\log \mathrm{T})$ is illustrated on figure 3. This distribution indicates clearly that the variables $\log T$ and $T$ are respectively normal and lognormal. The Khi-2 test shows that the adjustment of a normal distribution of $\log \mathrm{T}$ is suitable at the significance threshold of $10 \%$. This finding is in agreement with literature data as well for porous aquifers (Aboufarissi and Marino, 1984; Ahmed and de Marsily, 1987; Razack and Huntley, 1991) as for fractured aquifers (Fabbri, 1997; Jalludin and Razack, 2004; Razack and Lasm, 2006; Painter et al., 2007).

Table 1: Summary statistics of transmissivity $\left(T, \mathrm{~m}^{2} \cdot \mathrm{h}^{-1}\right)$ and specific capacity $\left(\mathrm{Q} / \mathrm{s}, \mathrm{m}^{2} \cdot \mathrm{h}^{-1}\right)$ data in Bondoukou area

\begin{tabular}{|l|c|c|c|c|c|c|c|}
\hline & & Number & Maximum & Minimum & Average & $\begin{array}{c}\text { Standard } \\
\text { deviation }\end{array}$ & $\begin{array}{c}\text { Coefficient of } \\
\text { variation }\end{array}$ \\
\hline \multirow{2}{*}{ All data } & $\mathrm{T}$ & 78 & 0.19320 & 0.00389 & 0.04260 & 0.03892 & 92.50 \\
\cline { 2 - 7 } & $\mathrm{log} \mathrm{T}$ & 78 & -0.71399 & -2.41027 & -1.53174 & 0.37898 & -24.74 \\
\hline \multirow{2}{*}{$\begin{array}{l}\text { Crystalline } \\
\text { data }\end{array}$} & $\mathrm{T}$ & 62 & 0.19320 & 0.00389 & 0.04456 & 0.04108 & 97.61 \\
\cline { 2 - 7 } $\begin{array}{l}\text { Schistes } \\
\text { data }\end{array}$ & $\mathrm{Q} / \mathrm{s}$ & 46 & 0.49549 & 0.00720 & 0.13398 & 0.10808 & 80.67 \\
\cline { 2 - 7 } & $\mathrm{T}$ & 16 & 0.06060 & 0.01068 & 0.03079 & 0.01465 & 47.58 \\
\hline
\end{tabular}




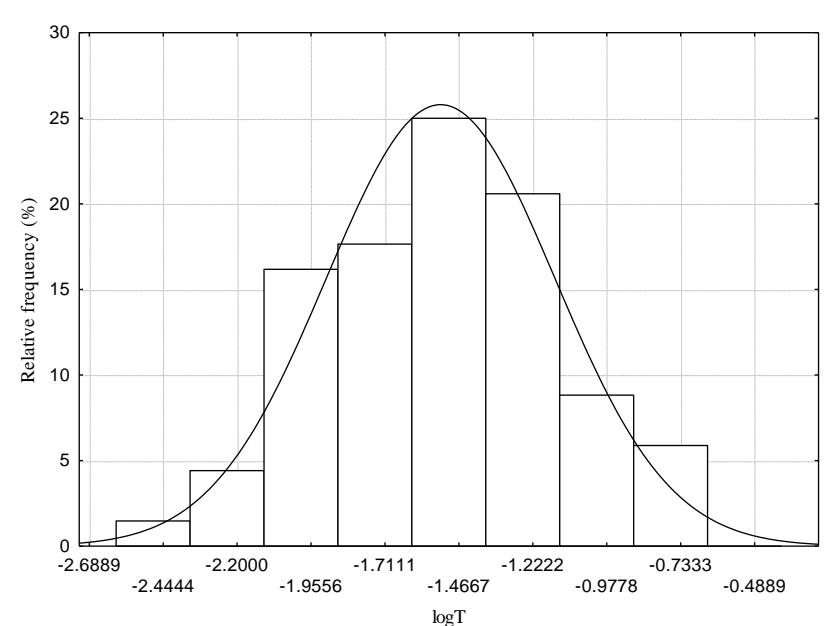

Fig. 3: Frequency distribution of $\log T$ (on crystalline and metamorphic area)

\section{METHODS}

The aquifer transmissivity is a parameter that is fundamental to any groundwater flow characterization and allows a better evaluation of hydrogeological properties of an aquifer. However, this parameter varies greatly in space and it is generally known at a few points because pumping test implementation is laborious and expensive. Transmissivity can be estimated on the whole study area using geostatistical methods. In the present study, kriging techniques will be used to assess the transmissivity of Bondoukou area aquifers. Transmissivity was regarded as regionalized variable, i.e. each value depends on its geographical position, and is treated by using geostatistical methods.

Variogram is defined by the following equations 1 and 2 for a given regionalised variable Z:

$$
\begin{aligned}
& \gamma(h)=\frac{1}{2} \operatorname{var}[Z(x+h)-Z(x)] \\
& \gamma(h)=\frac{1}{2} E\left[(Z(x+h)-Z(x))^{2}\right]
\end{aligned}
$$

Where $\operatorname{Var}[Z(x)]$ is the variance at point $x ; h$ is the vector of module $\left(x-x^{\prime}\right) ; E$ is the mathematical expectation. The geostatistical methods used in this study are variogram analysis and kriging technique. Kriging takes into account the spatial structure of the variable, characterized through the experimental variogram, which should previously be adjusted by a theoretical analytical model. The estimator $Z^{*}$ of the variable $Z$ at a point $x_{0}$ is given by equation (3):

$$
Z *=\sum_{i=1}^{N} \lambda_{i} Z\left(x_{i}\right)
$$

where, $Z^{*}$ is a linear estimator; $N$ is the number of values involved in the estimation; $\lambda_{i}$ are weights.

Two major conditions such as unbiasedness and optimality condition must be checked. The estimated errors (differences between the true values and the estimated values) should have a mean equal to zero and a minimum variance (see Razack and Lasm, 2006). The readers interested can see more detailed presentations and calculations in Journel and Huijbregts (1978), Isaak and Srivastava (1989) and Kitanidis (2000).

Data processing was performed using software GEOEAS (Englund and Sparks, 1991). The experimental variogram obtained here is modelled using the exponential function.

The different results of this study will be compared to the findings obtained from previous study (Lasm et al., 2008) in crystalline rocks, i.e. experimental variogram, kriging and standard deviations maps. A statistical analysis will be carried out with transmissivity data (estimated and raw data).

Before performing the kriging of the transmissivity $(\log T)$ on the whole study area (crystalline and metamorphic rocks), we checked if the two principal geological domains, i.e. crystalline and metamorphic rocks have the same hydrogeological behaviour. Transmissivity and specific capacity data of two domains were analysed. The summary statistics of the two variables ( $T$ and $Q / s$ ) is presented in the table 1. The average of the transmissivity on the both geological areas is $1.21 \mathrm{E}-05 \mathrm{~m}^{2} . \mathrm{s}^{-1}$ and $8.56 \mathrm{E}-06$ $\mathrm{m}^{2} \cdot \mathrm{s}^{-1}$ respectively on the crystalline and metamorphic rocks; while averages values of specific capacity are $0.10 \mathrm{~m}^{2} \cdot \mathrm{h}^{-1}$ and $0.13 \mathrm{~m}^{2} \cdot \mathrm{h}^{-1}$. These values are similar on statistic viewpoint, and indicate that both domains have similar hydrogeological behaviour. For this reason, it is reasonable to use all transmissivity data in crystalline and metamorphic rocks. The study area can be then considered as one medium. In this condition, kriging techniques can be used to assess transmissivity on the whole Bondoukou area.

Raw transmissivity $(\mathrm{T})$ values are transformed into logarithmic values $(\log \mathrm{T})$ before undertaking the geostatistical analysis. Variographic analysis is 
performed using the logarithmic transform of the data.

Cross validation procedure: The cross validation procedure aims to validate the structural models used to perform an estimate by kriging or cokriging. Its purpose is to analyse the estimation errors. In fact, the procedure eliminates a single value $\left(Z_{i}\right)$ from the data set and perform a kriged estimation $\left(Z_{i}^{*}\right)$ at this location. This is repeated for all the data set. Cross validation procedure compares actual values with estimated values. If the variogram model is valid, then the following results should be verified: the average of the actual errors should be zero and their variance $\left(\left(\sigma_{\mathrm{e}}{ }^{2}\right)\right.$ should be a minimum; the ratio of variance of actual errors to average kriging variance $\left(\left(\sigma_{\mathrm{e}}{ }^{2} / \sigma_{\mathrm{K}}{ }^{2}\right)\right.$ should be one. This procedure is described in details in Clark (1986), Gascuel-Odoux et al. (1994) and Razack and Lasm (2006).

\section{RESULTS}

Analysis of variograms of $\log \mathrm{T}$ : The omnidirectional experimental variograms of $\log T$ is calculated and reported on figure 4 . This diagram clearly displays, near the origin, a significant nugget effect $\left(C_{0}\right)$ representing about $63 \%$ of the total dispersion on this variogram. The spatial structure of the variogram of $\log T$ indicates that the variable $\log T$ behaves like a regionalized variable. Indeed, this experimental variogram is characterised by a sill $(C=$ $C_{0}+C_{1}$ ), a practical range (a) and a nugget effect $\left(C_{0}\right)$ (see Eq. 4). The practical range generally represents the distance over which a parameter is spatially correlated. The variogram has relatively large nugget effect, suggesting a large amount of randomness due to local-scale heterogeneity and/or measurement errors. On the figure 5 the experimental variogram of $\log T$ calculated by using solely the tranmissivity data on crystalline rocks is illustrated. This variogram presents again a larger nugget effect representing about $70 \%$ of the total dispersion. Nugget effect is usually encountered in geostatistical analysis. It is difficult on the variogram to separate the nugget effect in local scale heterogeneity from measurement errors. Transmissivity data available does not permit to describe this local scale heterogeneity. At large distances, the experimental variogram fluctuates around the sill, indicating a stationary phenomenon.

Comparative analysis of the variograms: In both studies, exponential theoretical model were used to fit the experimental variogram of logT (figures 4 and
5) and regionalized parameters have been determined. The expressions of the theoretical model fitted to the experimental variograms are written as follows (Eqs. 4 and 5):

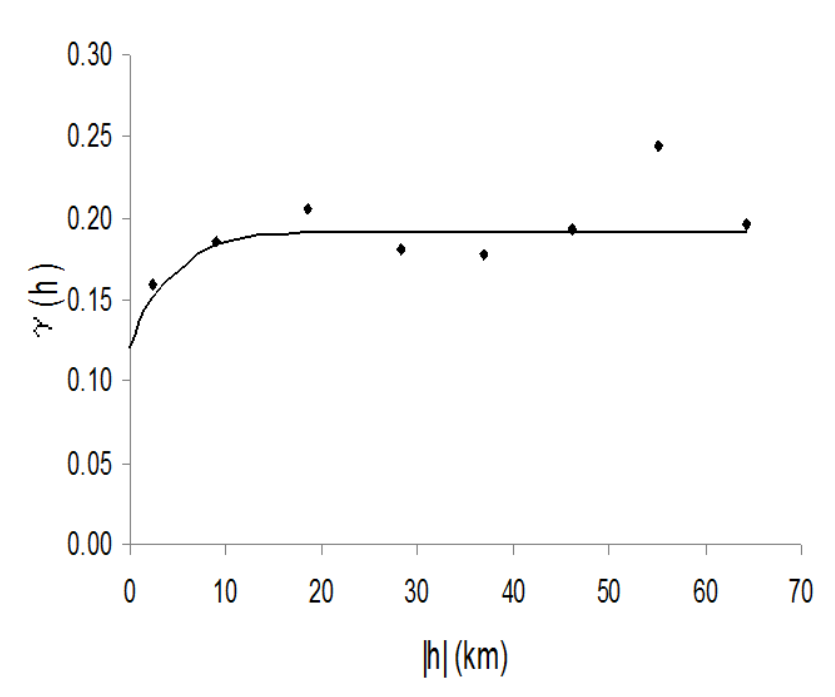

Fig. 4: Variogram of $\log T$ (data of crystalline and metamorphic rocks)

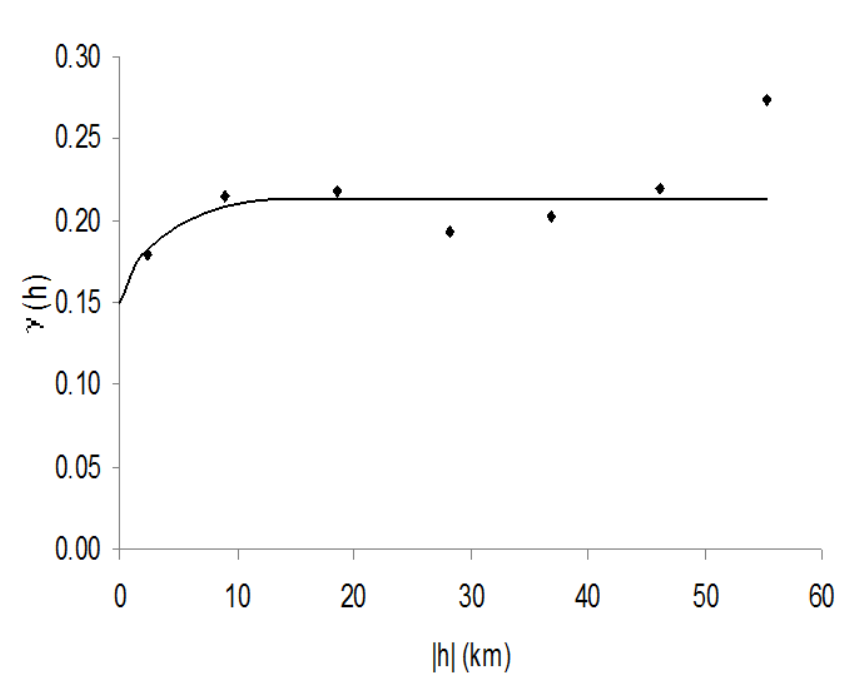

Fig. 5: Variogram of $\log T$ (data of the crystalline rocks) $\gamma(h)=0.12+0.072\left[1-\exp \left(-\frac{3 h}{12}\right)\right]$

$$
\gamma(h)=0.156+0.063\left[1-\exp \left(-\frac{3 h}{10}\right)\right]
$$


Equations 4 and 5 are respectively fitted models of the experimental variogram of $\log T$ in this study (crystalline and metamorphic rocks) and in the previous study (crystalline rocks) performed in the Bondoukou area.

The regionalization parameters (practical range, sill and nugget effect) characterize the spatial structure of $\log T$.

The two experimental variograms of logT (i.e. Eqs. 4 and 5) are compared. The following observations can be made:

The nugget effect $\left(C_{0}\right)$ is large in the two cases representing 63 and $70 \%$ respectively on crystalline and metamorphic rocks and on crystalline rocks solely. The large value of the nugget effect can be explained by the presence of aquifers in which transmissivity values are very variable on short or small extents. In crystalline rocks, the nugget effect is larger and can be explained by the size of the study sample. Indeed, the size of the sample can improve the experimental variogram quality. The variogram structure in this study is better because the nugget effect is less important than the one in the previous study. Indeed, the dispersion of the transmissivity is bigger in crystalline rocks than in crystalline and metamorphic rocks.

The practical range is big in both cases and is equal to $a=12 \mathrm{~km}$ and $a=10 \mathrm{~km}$ respectively. The practical range of variogram of logT on crystalline and metamorphic rocks is slightly higher than the range of variogram of $\log T$ on crystalline rocks.

It means that two points in the field separated by a distance less than the practical range remain correlated with each other. This large correlation length can be explained by the intensity of tectonic events in this area and connectivity of fractures network (Lasm et al., 2008). Indeed, the study of fracturing performed by Youan Ta (2008) and Youan Ta et al. (2008) using satellite images from the sensors of Landsat ETM+ showed the high density of fracturing and the presence of many longer fractures which size varies from 30 to $80 \mathrm{~km}$. This high density is favourable for good connectivity of fracture networks.
The comparison of sill $\left(C_{1}=C-C_{0}\right)$ shows that $C_{1}$ in the Eq. 4 is higher than the ones in Eq. 5. The fact to take into account the transmissivities of metamorphic rocks in this study improves slightly the experimental transmissivity variogram. This slight improvement can be explained by the numerous data recorded in this study $(n=78)$ that is more than in the first study $(n=$ 62). The finding on crystalline rocks will possibly be enhanced if available data of transmissivity is numerous.

The structure of the variogram $\log \mathrm{T}$ is better with Eq. 4 than Eq. 5, and can be used to represent spatial structuring of the transmissivity $(\log \mathrm{T})$ of Bondoukou area.

This finding will be explained by the transmissivity data number on the one hand and the spatial distribution of data on the other hand. Available data would play an important part in the variogram's logT structure and therefore will influence the quality of the estimator. Indeed, more the available data are numerous better will be the variogram.

Cross validation results: The variogram model given in equation (4) and available logT sample data (78 values) are used to perform an assessment of logT over the whole domain by using ordinary kriging (OK). Kriging has been carried out on a grid with a mesh size of $3 \mathrm{~km} \times 3 \mathrm{~km}$. A cross-validation procedure of the selected variogram model (Eq. 4) is carried out in order to check its validity. Using crossvalidation procedure, a comparison of the accuracy of this geostatistical models, was performed (table 2). The values found here for this theoretical model are the followings: $\mathrm{Me}=0.004618$ and $\sigma_{\mathrm{e}}{ }^{2} / \sigma_{\mathrm{K}}{ }^{2}=1.1098$. In this case, the average of the actual errors (Me) and the ratio $\left(\sigma_{\mathrm{e}}{ }^{2} / \sigma_{\mathrm{K}}{ }^{2}\right)$ are respectively close to 0 and 1. Consequently they are in conformity with theoretical values. It can be concluded that the exponential variogram model used in this study is valid. The frequency distribution of estimate errors $\left(\log T^{*}-\log T\right)$ is shown on figure 6 . The frequency distribution is symmetrical and centred around zero. This distribution can be described by a normal law, which is also an indication of model validity. 
Am. J. Sci. Ind. Res., 2012, 3(5): 315-330

Table 2: Cross validation results when using Eq. 4 (on crystalline and metamorphic rocks)

\begin{tabular}{|l|c|c|c|c|c|c|}
\hline & Actual logT & Kriged logT & Kriging SD & $\begin{array}{c}\text { Kriging } \\
\text { variance }\end{array}$ & Actual error & $\begin{array}{c}\text { Actual } \\
\text { error/kriging SD }\end{array}$ \\
\hline Minimum & -2.4103 & -1.9548 & 0.3486 & 0.1215 & -0.9646 & -2.3091 \\
\hline Maximum & -0.7140 & -1.2986 & 0.4882 & 0.2384 & 0.8381 & 2.0942 \\
\hline Average & -1.5317 & -1.5226 & 0.3852 & 0.1489 & 0.0046 & 0.0172 \\
\hline Variance & 0.1436 & 0.0238 & & & 0.1652 & 1.0980 \\
\hline $\begin{array}{c}\text { Standard } \\
\text { deviation }\end{array}$ & 0.3790 & 0.1543 & & & 0.4065 & 1.0478 \\
\hline
\end{tabular}

T expressed in $\mathrm{m}^{2} \cdot \mathrm{h}^{-1}$

$\mathrm{SD}=$ Standard deviation

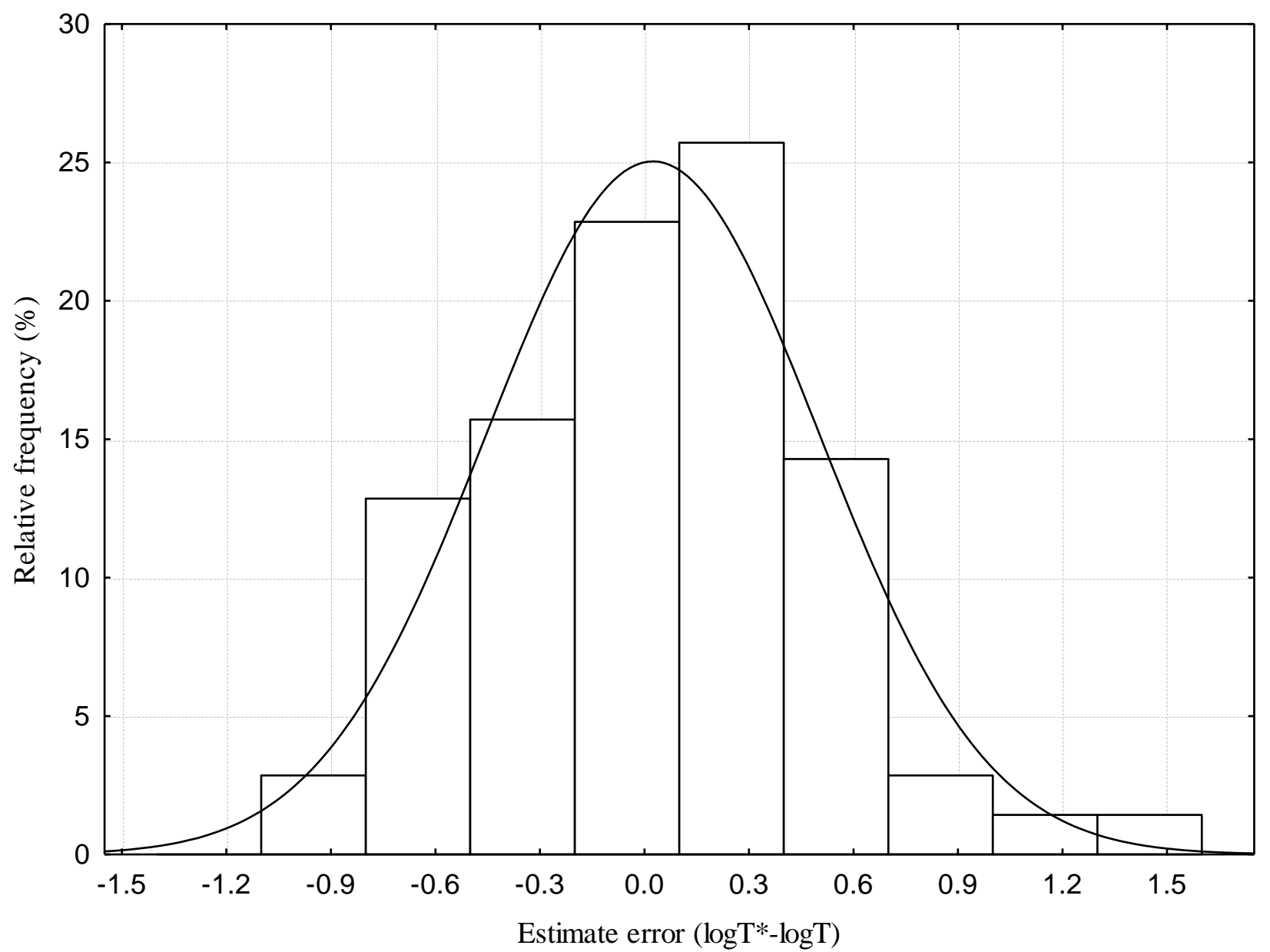

Fig. 6: Frequency distribution of logT estimate errors (on crystalline and metamorphic rocks)

Assessment of transmissivity of Bondoukou area: The krigged estimation of $\log T$ is shown on figure $7 \mathrm{a}$ and the kriging standard deviations map is shown on figure 8a. Kriging procedure calculates the estimation variance (or its square-root, the estimation standard deviation). It can be noted on this map that, some sectors of low and strong values of kriging standard deviation. The estimates map (kriged $\log \mathrm{T}$ ) presented in certain places more or less a smoothed aspect. It is a feature which is usually seen in the assessment of regionalized variable. Kriged $\log T$ and 
standard deviations maps obtained in crystalline rocks (first study, $\mathrm{n}=62$ ) are illustrated respectively on figures $7 \mathrm{~b}$ and $8 \mathrm{~b}$. The estimation standard deviations map constitutes an indication of quality of the estimates. The smaller the standard deviation value, the higher the accuracy of estimates. Highest values of the estimation standard deviations are found towards boundaries of study area and in the parts poor in data. Kriging standard deviation oscillates between 0.131 and 0.256 . These high values can be explained by the skin effect and the presence of zones where data points are lacking or are very few (poor).

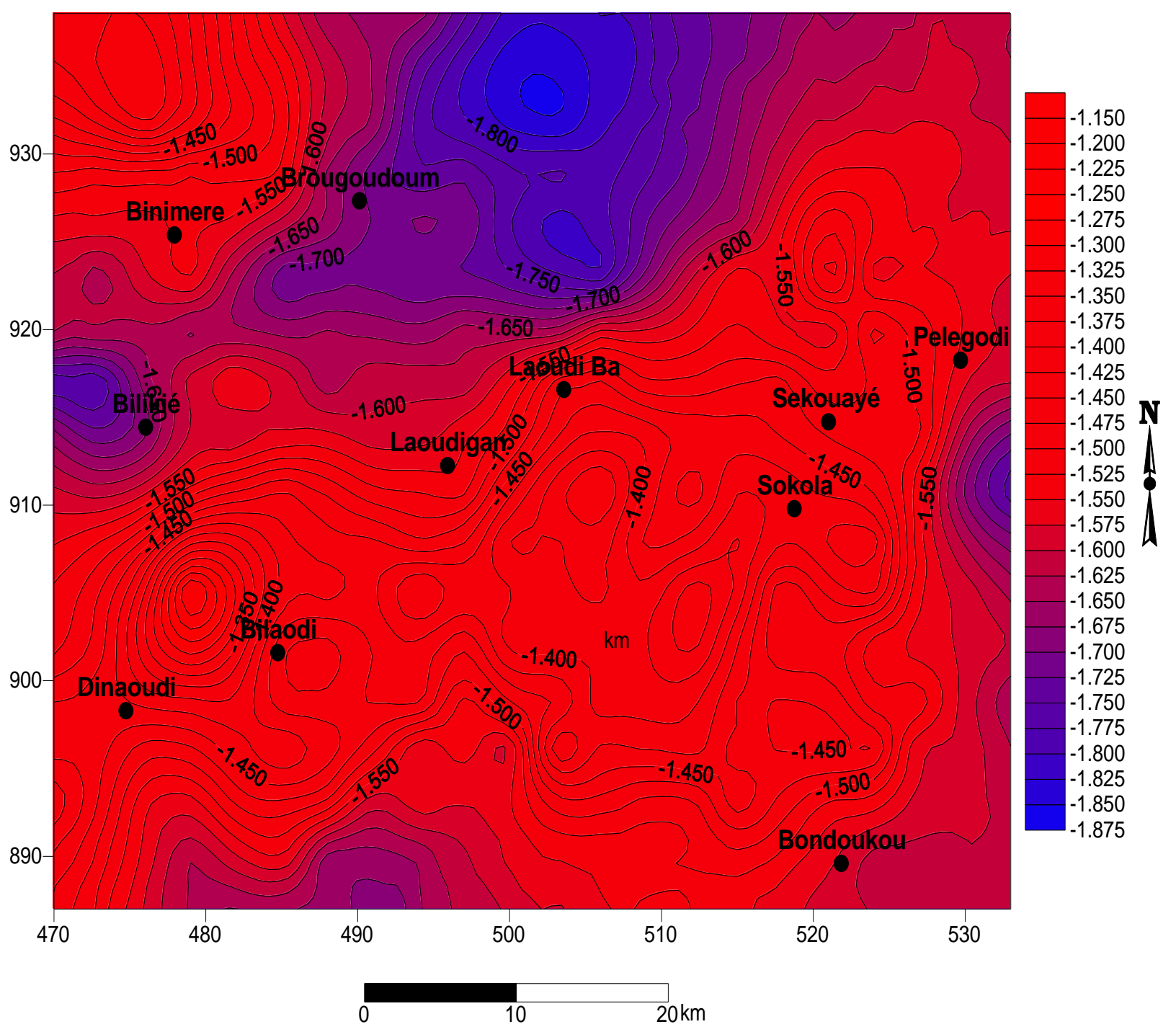

Fig. 7a: Kriged logT map using transmissivity data of crystalline and metamorphic rocks 
Am. J. Sci. Ind. Res., 2012, 3(5): 315-330

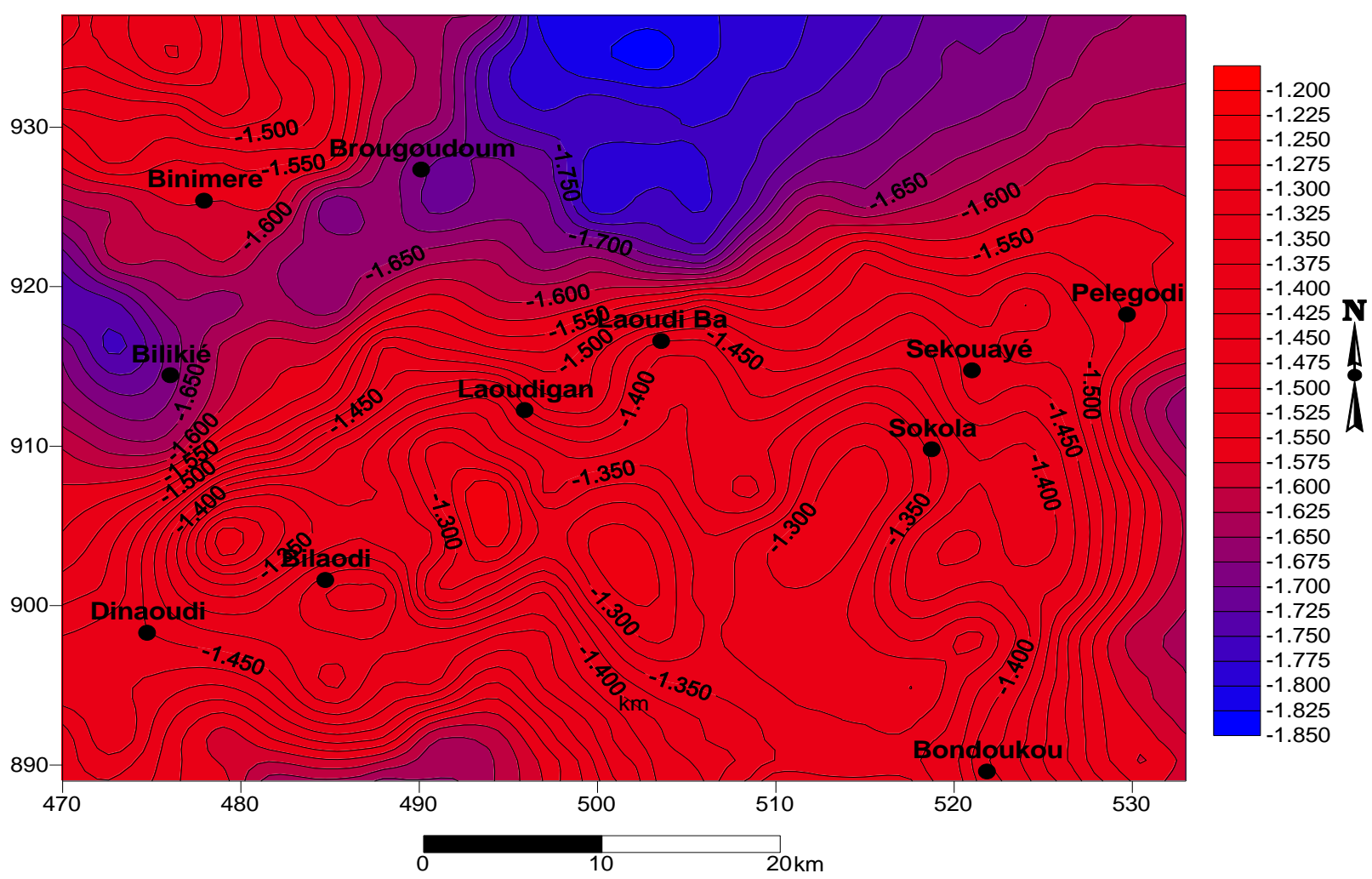

Fig. 7b: Kriged logT map using transmissivity data of the crystalline rocks

The estimated transmissivity values are mapped on These maps are obtained after a backtransform of $\log \mathrm{T}$ to $\mathrm{T}$.

figures $9 a$ and $9 b$ respectively on crystalline and

metamorphic rocks and on solely crystalline rocks.

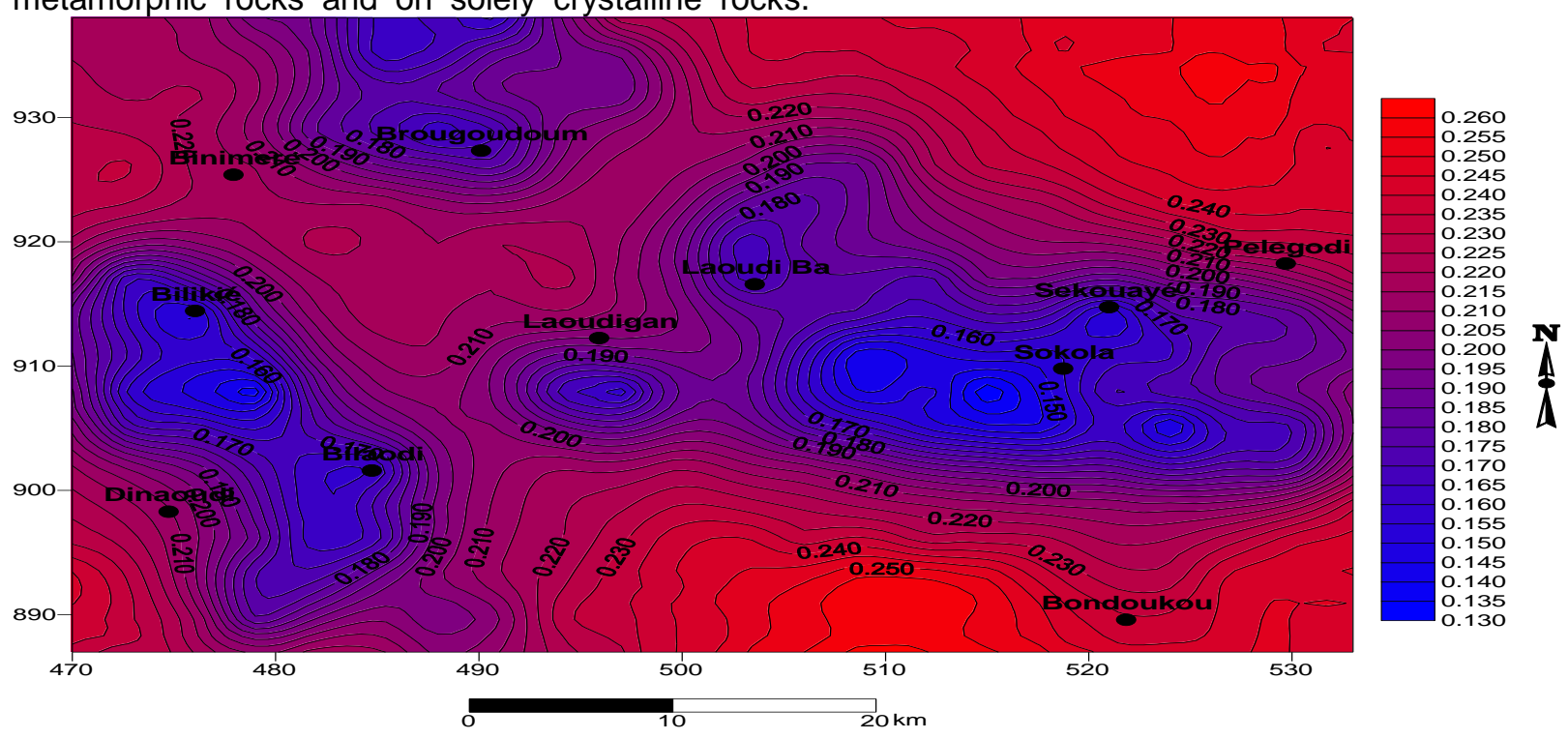

Fig. 8a: logT kriging standard deviations map (on crystalline rocks and metamorphic rocks) 
Am. J. Sci. Ind. Res., 2012, 3(5): 315-330

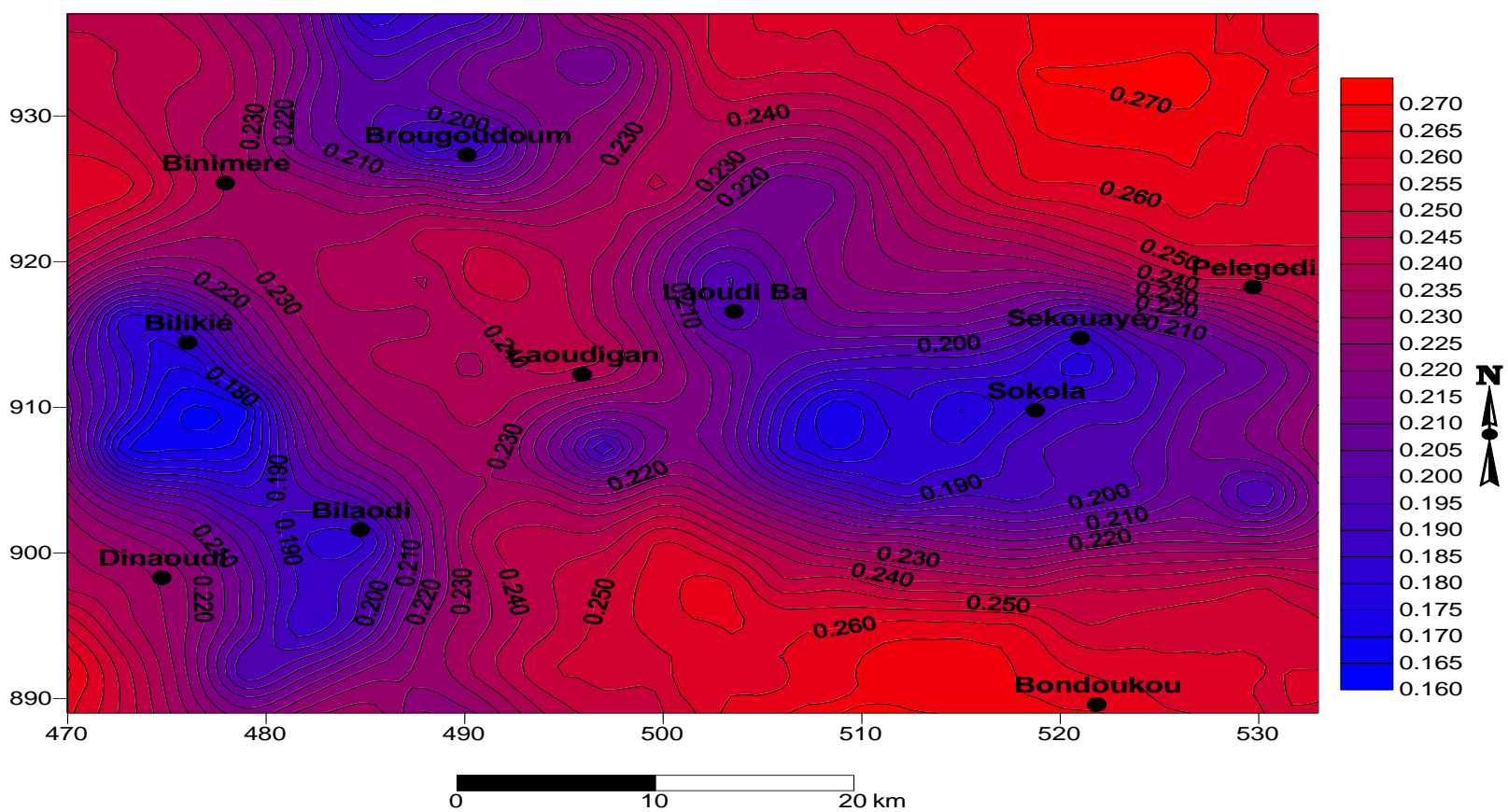

Fig. 8b: logT kriging standard deviations map (on crystalline rocks)

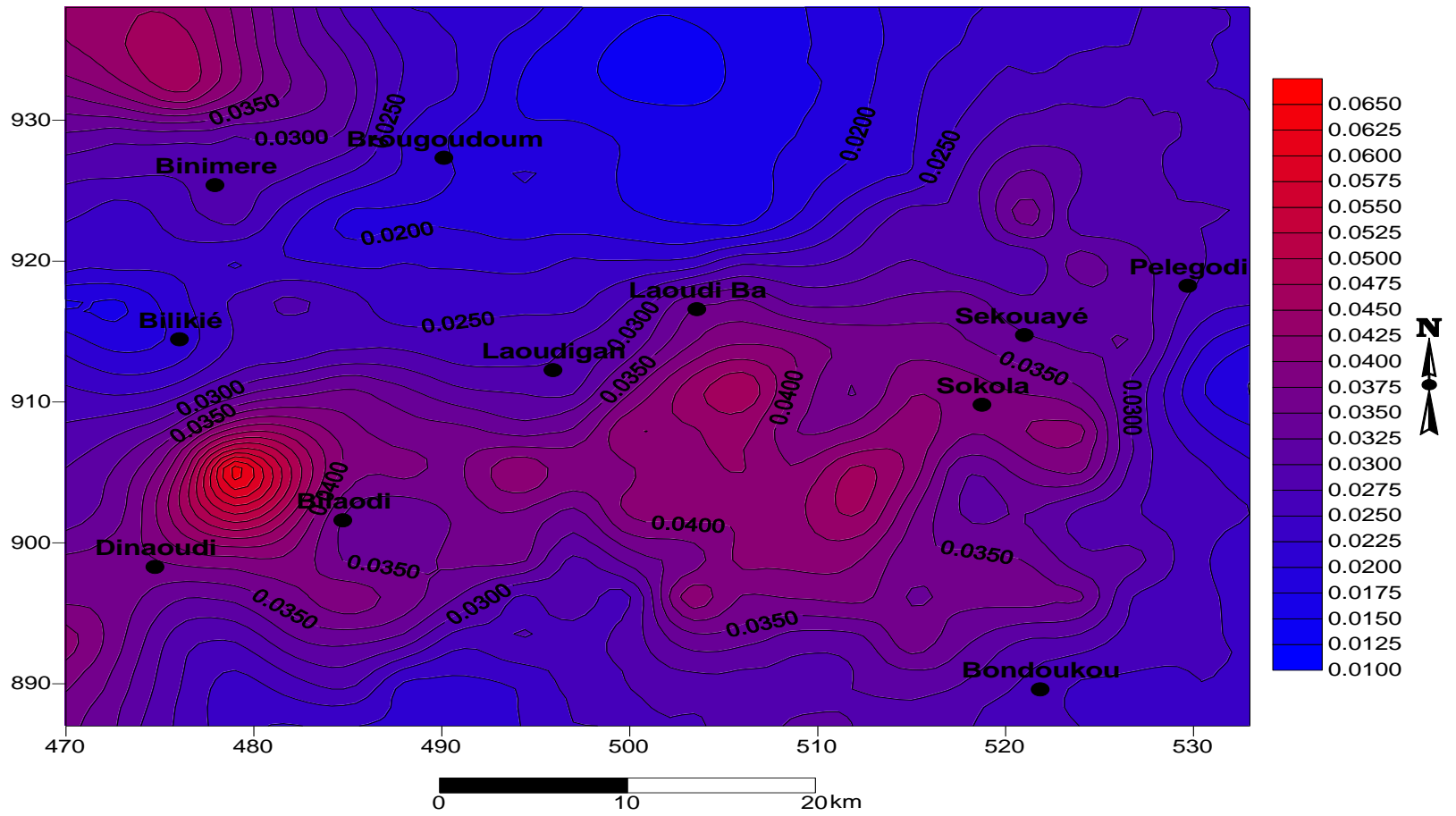

Fig. 9a: Transmissivity estimation map obtained by a backtransform of log $\mathrm{T}$ to $\mathrm{T}$ (on crystalline and metamorphic rocks) 
Am. J. Sci. Ind. Res., 2012, 3(5): 315-330

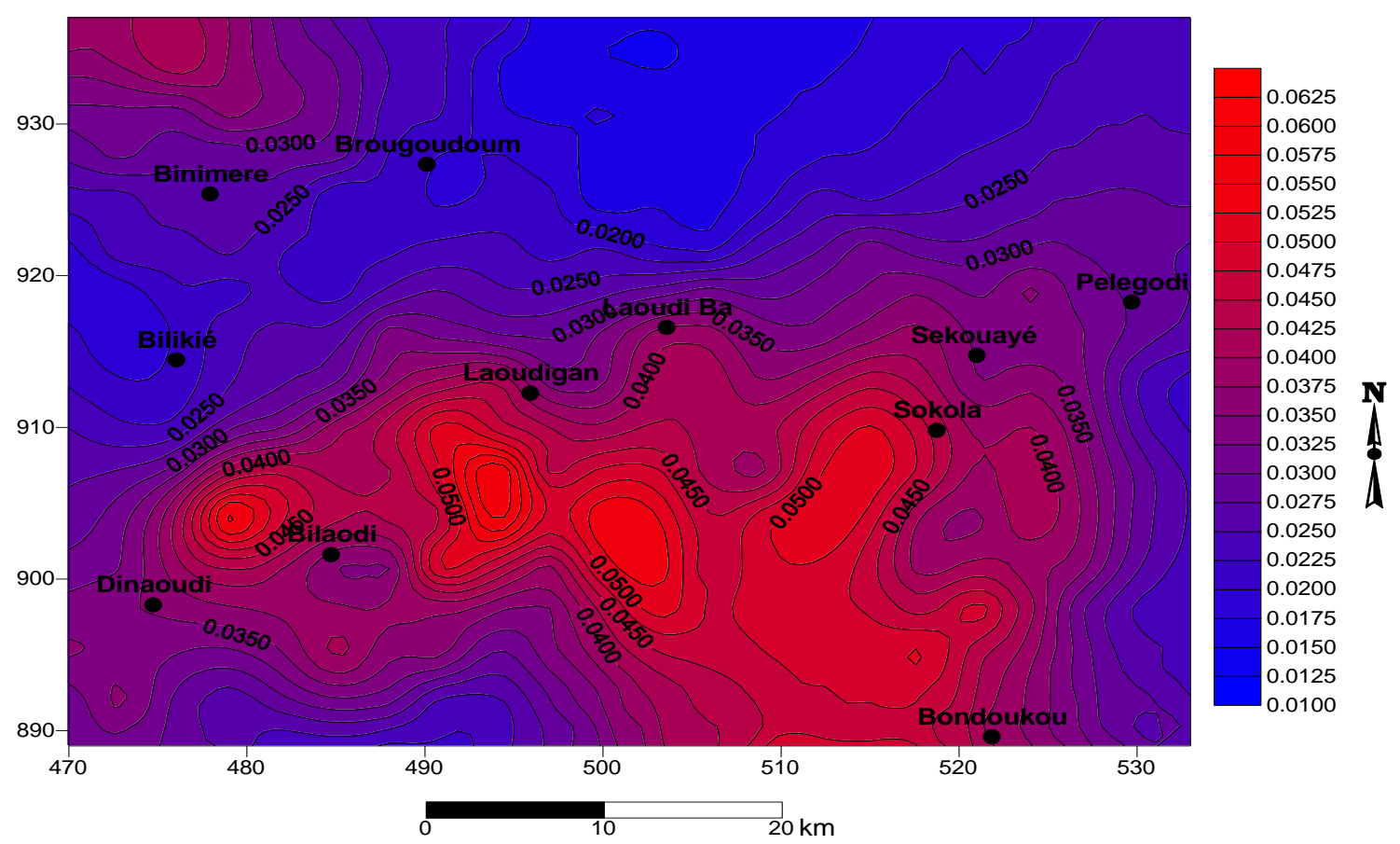

Fig. 9b: Transmissivity estimation map obtained by a backtransform of logT to $T$ (on crystalline rocks)

\section{DISCUSSION}

Kriging estimation has been performed on two areas: i) on solely crystalline rocks, ii) on crystalline and metamorphic rocks; the aim being a better knowledge of the transmissivity in Bondoukou area.

Cross-validation results of these different studies are shown in tables 2 and 3 . Analysis of these tables shows that in both cases, the results are satisfactory.
Indeed, average of the actual errors and variance ratio of the actual errors to the average kriging variance are respectively closed to zero and one. However, it can be noted that the cross validation results of crystalline rocks $(\mathrm{Me}=-0.02707$ and $\sigma \mathrm{e}^{2} / \sigma \mathrm{k}^{2}=0.92381$ ) are lower than these of crystalline and metamorphic rocks ( $\mathrm{Me}=0.00461$ and $\left.\sigma \mathrm{e}^{2} / \sigma \mathrm{k}^{2}=1.10979\right)$. We can conclude that the structural models used in these studies are valid.

Table 3: Cross validation results when using Eq. 5 (on crystalline rocks)

\begin{tabular}{|l|c|c|c|c|c|c|}
\hline & Actual logT & Kriged logT & Kriging SD & $\begin{array}{c}\text { Kriging } \\
\text { variance }\end{array}$ & Actual error & $\begin{array}{c}\text { Actual error/ } \\
\text { Kriging SD }\end{array}$ \\
\hline Minimum & -2.4103 & -2.0788 & 0.4308 & 0.1856 & -0.9729 & -2.0061 \\
\hline Maximum & -0.7140 & -1.1448 & 0.5495 & 0.3019 & 0.8594 & 1.8236 \\
\hline Average & -1.5199 & -1.5291 & 0.4619 & 0.2138 & -0.0271 & -0.0159 \\
\hline Variance & 0.1585 & 0.0404 & & & 0.1909 & 0.8644 \\
\hline $\begin{array}{l}\text { Standard } \\
\text { deviation }\end{array}$ & 0.3981 & 0.2011 & & & 0.4369 & 0.9297 \\
\hline
\end{tabular}

T expressed in $\mathrm{m}^{2} \cdot \mathrm{h}^{-1}$

$\mathrm{SD}=$ Standard deviation

After the cross validation, kriging results (standard deviation of the errors of estimate, estimate values $(\log T)$, backtransform of $\log T$ to $T)$ are analysed from a statistical viewpoint and maps are compared.

Observed values in present study range between $1.08 \mathrm{E}-06 \mathrm{~m}^{2} . \mathrm{s}^{-1}$ and $5.36 \mathrm{E}-05 \mathrm{~m}^{2} . \mathrm{s}^{-1}$; while estimated values range between $3.86 \mathrm{E}-06 \mathrm{~m}^{2} \cdot \mathrm{s}^{-1}$ and $1.84 \mathrm{E}-05$ $\mathrm{m}^{2} . \mathrm{s}^{-1}$. Observed and estimated values of transmissivity are comparable generally. Observed and estimated values of the transmissivity spread over two orders of magnitude respectively. The average values are respectively $1.16 \mathrm{E}-05 \mathrm{~m}^{2} . \mathrm{s}^{-1}$ and $8.42 \mathrm{E}-06 \mathrm{~m}^{2} . \mathrm{s}^{-1}$, and the standard deviation values are $1.08 \mathrm{E}-05 \mathrm{~m}^{2} \cdot \mathrm{s}^{-1}$ and $2.30 \mathrm{E}-06 \mathrm{~m}^{2} \cdot \mathrm{s}^{-1}$. In both 
cases, the average and standard deviation values are comparable.

In the previous study i.e. on the crystalline rocks the following results are obtained (using Eq. 5): Observed values range between $1.08 \mathrm{E}-05 \mathrm{~m}^{2} . \mathrm{s}^{-1}$ and $5.36 \mathrm{E}-05 \mathrm{~m}^{2} . \mathrm{s}^{-1}$; while the estimated values range between $4.00 \mathrm{E}-06 \mathrm{~m}^{2} . \mathrm{s}^{-1}$ and $1.72 \mathrm{E}-05 \mathrm{~m}^{2} . \mathrm{s}^{-1}$. The average values are respectively $1.21 \mathrm{E}-05 \mathrm{~m}^{2} . \mathrm{s}^{-1}$ and $9.17 \mathrm{E}-06 \mathrm{~m}^{2} \cdot \mathrm{s}^{-1}$, and standard deviation values are $1.14 \mathrm{E}-05 \mathrm{~m}^{2} . \mathrm{s}^{-1}$ and $2.86 \mathrm{E}-06 \mathrm{~m}^{2} . \mathrm{s}^{-1}$. The observed and estimated transmissivity values spread over two orders of magnitude.

These results indicate that from a statistical viewpoint, both observed and estimated transmissivity data sets are similar.

In the first and present studies, the estimated values are comparable and similar from a statistical viewpoint.

Krigged $\log T$ maps using Eq. 4 and Eq. 5 are illustrated respectively on figures $7 \mathrm{a}$ and $7 \mathrm{~b}$. The estimated $\log T$ oscillate respectively between -1.86 and -1.18 and between -1.84 and -1.21. The values of $\log T$ in both studies are comparable from a statistical viewpoint, the amplitude of these values is 0.68 on crystalline and metamorphic rocks and 0.63 on crystalline rocks. The amplitude of estimates logT is slightly important in present study. This result is in agreement with the standard deviation of the errors of estimate (kriging standard deviation) values. On these two maps, the same parts of smaller and higher values of kriging $\log T$ can be observed. The sectors of smaller values are found principally in south-western, eastern and western to northern parts of Bondoukou area.

The standard deviation of the errors of estimate (SDEE) ranges between 0.13 and 0.26 in the current study and between 0.16 and 0.27 in the previous study. It's clearly illustrates that the SDEE of estimate is less important in this study than in the first study. This is an indication of the quality of the assessment. Indeed, the standard deviation of the errors of estimate is an indicator of the confidence to be granted to the kriging estimates. To allow a good comparison, kriging maps of the two studies (kriging $\log T$, standard deviation of the errors of estimate and backtransform $\log T$ to $T$ ) are plotted in the same colour (blue and red respectively for smaller and higher values) and have the same equidistance (see figures 7 to 9). Analysis indicates that: i) more than $12 \%$ of standard deviation of the errors of estimate (i.e. SDEE < 0.16) in this study is lower than the smallest of SDEE in the first study; ii) and $3 \%$ (i.e. SDEE > 0.26) of this SDEE in the first study is larger than the strongest value of the SDEE in this study.

Therefore $88 \%$ of SDEE values obtained in this study is more or less similar to those obtained in the first study. In conclusion, kriging standard deviation values in crystalline and metamorphic rocks (using Eq. 4) are generally better than those in crystalline rocks (using Eq. 5). On SDEE maps (figures $8 a$ and b), the sectors with large values of standard deviation are located in the same sectors i.e. in the northeastern and south-eastern parts of the study area. The results are in agreement with field observation (see figure 1). Indeed, they are very few or no data available in these parts, it can be reasonably stated that the standard deviation values are larger in this part. However, SDEE is smaller in the parts where transmissivity data are available. On figure $8 \mathrm{~b}$ (on crystalline rocks), the areas covered by larger values of SDEE are more important than the ones on figure $8 a$ (on crystalline and metamorphic rocks). This result can be explained by the fact that there are numerous transmissivity data in this study $(n=78)$ than in the first study $(n=62)$. On the figure $8 a$, the smaller values of standard deviation are met at Sokola, Laoudi $\mathrm{Ba}$, Sekouaye localities on the one hand, Dinaoudi and Bilaodi localities on the other hand. These localities are located in the centre-eastern and south-western parts of study area. Let's note that the values of SDEE inferior to 0.16 are not met in the kriging standard deviation map obtained on crystalline rocks (figure $8 b$ ). On figure $8 \mathrm{a}$, there is no standard deviation values which are larger than 0.26 , that is an important finding which indicates quality of transmissivity estimation. The kriging standard deviation map obtained in this study (figure 8a) is therefore better than the ones of the first study (figure $8 b)$.

The accuracy of estimated transmissivity map can be, to some extent, interpreted with the use of the kriging standard deviation related to $\log T$ kriging. We can assume that places where logT estimates are not reliable, estimates of $T$ (obtained through a backtransform) are also not reliable. Kriging standard deviation varies very little in crystalline and metamorphic rocks $(0.13$ to 0.26$)$. Note however that, towards the boundaries of study area (north-east, south-east and north-west parts), kriging standard 
deviation increase gradually. Thus estimates become less and less reliable but stay acceptable. Areas of good estimation are numerous and occupy a large extension on study area. These areas of good estimation are principally located at the centre (Sokola Laoudi Ba localities), south-west (Bilikié and Bilaodi localities) and north parts (Brougoudoum locality). Reliable and less reliable estimate zones are well distinguished on the kriging standard deviations map (figures $8 \mathrm{a}$ and $8 \mathrm{~b}$ ). In parts where data available are numerous, kriging standard deviations are lower and the estimates are reliable and can be accepted (see figures 1 and 8 ).

The kriging map remains despite everything an estimate, which although being optimal, doesn't respect strictly the entirety of real spatial variability of the phenomenon being analyzed. It is conceived easily that such a difference can exist between the phenomenon in its reality and its kriging estimate (Razack, 1984).

We will retain in this study that generally, kriging standard deviations map shows that assessment of the transmissivity of Bondoukou area is coherent. There is compatibility between estimated values and observed values of transmissivity. In two studies, findings obtained are reliable and acceptable. However, the comparison of findings from two studies demonstrates that transmissivity assessment is clearly good when we take into account transmissivity in crystalline and metamorphic rocks. Indeed, values of standard deviation of the errors of estimate are the lowest.

The transmissivity assessment on basement fractured aquifer of Bondoukou area has been improved with transmissiviy on crystalline and metamorphic rocks by using the variogram of Eq.4. On this basis, estimates of transmissivity of Bondoukou area proved coherent and are acceptable. These estimates of transmissivity can therefore be use for groundwater simulation and groundwater modeling to understand the groundwater flow dynamics in the fractured crystalline basement of Bondoukou area .

The findings in this study notably estimates values are representative of transmissivity on Bondoukou area and are important and very interesting for a good knowledge of fractured aquifers parameters.
CONCLUSION: This study aim was to improve the assessment of transmissivity of the highly fractured aquifers of Bondoukou area using kriging technique. The main findings of this study are summarised as follows:

- Actual transmissivity values in Bondoukou area are spread over two orders of magnitude, revealing the heterogeneity of the Bondoukou aquifer. The geostatistical analysis indicates that the transmissivity $(\log T)$ is a regionalized variable. The variogram of $\log T$ is characterised by a significant nugget effect representing more $63 \%$ of total dispersion. The practical range is equal to $12 \mathrm{~km}$, which is important and would show good connectivity of the fractures networks of Bondoukou area. The variogram structure in this study is better than the one obtained in the previous study.

Cross validation results showed that the condition of unbiasedness and optimality are met in this approach. Estimate transmissivity range between 3.86E-06 and 1.84E-05 m². $\mathrm{s}^{-1}$ and between 4.00E06 and $1.72 \mathrm{E}-05 \mathrm{~m} 2 . \mathrm{s}^{-1}$ respectively in this study and previous study. In both studies (observed and estimated values), the amplitudes of variation of transmissivities are identical. Estimates values on the study area are generally coherent and compatible with the raw data. Transmissivity assessment of Bondoukou area has been improved using available transmissivity data on crystalline and metamorphic rocks.

The comparison of two studies showed that the results of the current study (using Eq. 4) are better than the result of the previous study (using Eq. 5).

The use of the kriging technique has permitted a better knowledge of this important hydraulic parameter on the study area. This improvement of knowledge about these aquifers is a basic stage that will permit to undertake further tasks regarding the modelling of these aquifers.

\section{ACKNOWLEDGEMENTS:}

The authors would like to gratefully thank the anonymous reviewers for their comments and suggestions, and to the responsibles of the Department of Ministry of the Economic Infrastructures of the Bondoukou area (Côte d'Ivoire) for the data used in this study. 


\section{REFERENCES}

Aboufirassi, A., Marino, M.A. (1984). Cokriging of aquifer transmissivity from field measurements of transmissivity and specific capacity. Mathematic and Geology 16(1): 1935.

Ahmed, S., de Marsily, G. (1987). Comparison of geostatistical methods for estimating transmissivity using data on transmissivity and specific capacty. Water Resource Research 23 (9): 1717-1737.

Ahmed, S., de Marsily, G. (1993). Cokriged estimation of aquifer transmissivity as an indirect solution of the inverse problem: A pratical approach. Water Resource Research 29 (2): 521-530.

Baka, D., Lasm, T., Oga, M-S., Youan Ta, M., De Lasm, O., Kouakou, S.O., Ettien F.B (2011). Characterization of transmissivity in the fractured reservoirs in the Oumé area (Centre of Cote d'Ivoire). American Journal of Scientific and Industrial Research 2(2): 310-322.

Biémi, J. (1992). Contribution à l'étude géologique, hydrogéologique et par télédétection des bassins versants sub-saheliens du socle précambrien d'Afrique de l'Ouest: Hydrostructurale, hydrodynamique, hydrochimie et isotopie des aquifères discontinus de sillons et aires granitiques de la Haute Marahoué (Côte d'Ivoire). PhD Thesis, University of Abidjan, Côte d'Ivoire, 493 p.

Boucher, M., Favreau, G., Vouillamoz, J. M., Nazoumou, Y., Legchenko, A. (2009). Estimating specific yield and transmissivity with magnetic resonance sounding in an unconfined sandstone aquifer (Niger). Hydrogeology Journal 17: 1805-1815.

Camil, J. (1984). Pétrographie, chronologie des ensembles granulitiques archéens et formations associées de la région de Man (Côte d'Ivoire). Implication pour l'histoire géologique du craton Ouest-africain. $\mathrm{PhD}$ Thesis, University of Abidjan, Côte d'Ivoire, 306 p.

Clark, I. (1986). The art of cross validation in geostatistical applications. Proceedings $19^{\text {th }}$ International APCOM Symposium, Pennsylvania State University, April, 211220

De Marsily, G., Delhomme, J.P., Delay, F., Buoro, A. (1999). Regards sur 40 ans de problèmes inverses en hydrogéologie. Comptes Rendus Académie des Sciences Paris, Sciences de la Terre et des planètes/ Earth \& Planetary Sciences 329: 73-87.

Delor, C., Siméon, Y., Vidal, M., Zeade, Z., Koné, Y., Adou, M., Dibouahi, J., Irié, D.B., Ya, B.D., N'da, D., Pouclet, A., Konan, G., Diaby, I., Chiron, J.C., Dommanget, A., Kouamelan, A.N., Peucat, J.J., Cocherie, A., Cautru, J.P. (1995). Carte géologique de la Côte d'Ivoire à 1/200 000, feuille Nassian. Mémoire de la Direction des Mines et de la Géologie 9, Abidjan- Côte d'Ivoire.

Djro, S.C. (1998). Evolution tectono-métamorphiques des gneiss granulitiques archéens du secteur de Biankouma. PhD Thesis, University of Abidjan, Côte d'Ivoire, $171 \mathrm{p}$.
Englund, E., Sparks, A. (1991). GEO-EAS, Geostatistical Environmental Assessment Software. US Env Protec Ag 600/8-91/008, $186 \mathrm{p}$.

Fabbri, P. (1997). Transmissivity in the geothermal Euganean Basin: a geostatistical analysis. Ground Water 35(5): 881887.

Faillat, J.P. (1986b). Hétérogénéité et effet d'échelle dans les aquifères fissurés. Approche par pompage d'essai sur station expérimentale (Afrique de l'Ouest). Hydrogéologie 1: $65-76$

Faillat, J.P (1986a). Aquifères fissurés en zone tropicale humide: structure, hydrodynamique et hydrochimie (Afrique de l'Ouest). PhD Thesis, University of Montpellier II, $534 \mathrm{p}$.

Faillat, J.P, Leblond P. (1982). Premiers résultats des essais menés sur une station de pompage expérimental en Côte d'Ivoire. Document B.R.G.M. 45: 301-314.

Gascuel-Odoux, C., Bovin, P., Walter, C. (1994). Eléments de géostatistiques. In: Des processus pédologiques. Ed. Actes, 217-247.

Gupta, C.P. (1989). On analysis of step drawdown test data. Ground Water 27(6): 874-880.

Helweg O.J. (1994). A general solution to the step-draw-down test. Ground Water 32(3): 363-365.

Isaak, E.H., Srivastava, M.R (1989). An introduction to applied geostatistics. Oxford University Press, New York, 561 p.

Jalludin M., Razack M. (2004). Assessment of hydraulic properties of sedimentary and volcanic aquifer systems under arid conditions in the Republic of Djibouti (Horn of Africa). Hydrogeology Journal 12: 159-170.

Jourda, J.P (2005). Méthodologie d'application des techniques de télédétection et des systèmes d'information géographique à l'étude des aquifères fissurés d'Afrique de l'ouest. Concept de l'Hydrotechniquespatiale: cas des zones tests de la Côte d'Ivoire. PhD Thesis, University of Cocody-Abidjan, Côte d'Ivoire, $429 \mathrm{p}$.

Journel, A.G, Huijbregts, C.J (1978). Mining geostatistics. Academic Press, New York, 600 p.

Kawecki, M.W. (1993). Recovery analysis from pumping tests with stepped discharge. Ground Water 31(4): 585-592.

Kawecki, M.W. (1995a). Meaningful interpretation of stepdrawdown test. Ground Water 33(1): 23-32.

Kitanidis, P.K. (2000). Introduction to Geostatistics. Application in Hydrogeology. Cambridge Univ. Press, Cambridge, UK.

Kouamelan, A.N (1996). Géochronologie et géochimie des formations archéennes et protérozoïques de la dorsale de Man en Côte d'Ivoire. Implications pour la transition Archéen-Protérozoïque. PhD Thesis, University of Rennes 1 (France), 284 p.

La Barbera, P., Rosso, R. (1989). On the fractal dimension of stream networks, Water Resour. Res. 25 (4): 735-741. 
Lasm, T. (2000). Hydrogéologie des réservoirs fracturés de socle: Analyse statistique, et géostatistique de la fracturation et des propriétés hydrauliques. Application à la région des Montagne de Côte d'Ivoire (Domaine archéen). PhD Thesis, University of Poitiers (France), 274 p.

Lasm, T., Kouamé, F., Oga, MS., Jourda, J.P, Soro, N., Kouadio, B.E (2004). Etude de la productivité des réservoirs fracturés des zones de socle. Cas du noyau archéen de Man-Danané (Ouest de la Côte d'Ivoire). Revue Ivoirienne des Sciences et Technologie 5: 97-115.

Lasm, T., Razack, M. (2001). Lois d'échelle dans la fracturation des roches dures cristallines et dans le réseau hydrographique associé. Compte Rendu Académie des Sciences Paris, Science de la Terre et des planètes 333: 225-232.

Lasm, T., Youan Ta, M., Jourda, P., Baka, D., Kouakou, O.S, De Lasme, O.Z, Soro, N. (2009). Contribution à une meilleure estimation de la transmissivité dans les aquifères discontinus de socle de la région de Bondoukou (Nord-Est de la Côte d'Ivoire). $2^{\text {ème }}$ Journée des Sciences Géologiques, 05 Août 2009, Résumés, Université de Cocody, Abidjan-Côte d'Ivoire.

Lasm, T., Youan, Ta, M., Razack, M. (2008). Geostistical analysis of the transmissivity in fissured reservoirs of Bondoukou Region (northeast, Côte d'Ivoire). in the IAHSelected Papers book series titled: Applied Groundwater Studies in Africa - Segun Adelana, Alan MacDonald, Tamiru Alemayehu \& Callist Tindimugaya (editors); Publishers: Taylor \& Francis, The Netherlands, 473-485.

Mace, R.E., Smyth, R.C., Xu, L., Liang, J. (1999). Transmissivity, Hydraulic conductivityand storativity of the Carrizo-Wilcox aquifer in Texas: Bureau of Economic Geology, The University of Texas at Austin, submitted to the Texas Water Development Board, $76 \mathrm{p}$.

Onetié, O.Z., Lasm, T., Baka, D., Fossou, N.M.R., Kouakou, S.O., Youan Ta, M., De Lasme, O., Oga, M.S., Soro, N. (2010). Influence des pertes de charges quadratiques sur la transmissivité et le débit spécifique déterminés sur des forages isolés : cas de la région de Korhogo au nord de la Côte d'Ivoire). Revue Ivoirienne des Sciences et Technologie 16 : 261-283.

Painter, S.L, Woodbury, A.D, Jiang, Y. (2007). Transmissivity estimation for highly heterogeneous aquifers: comparison of three methods applied to the Edwards aquifer, Texas, USA. Hydrogeology Journal 15: 315-331.

Phillips, J.D (1993). Interpreting the fractal dimension of river networks, in: Lam N.S.N., De Cola L. (Eds.), Fractals in Geography, chap. 7, Prentice-Hall, Englewood Cliffs, NJ,

Razack, M. (1984) Application des méthodes numériques à l'identification des réservoirs fissurés carbonatés en hydrogéologie. PhD Thesis, University of Languedoc, Montpellier, France, $384 \mathrm{p}$.

Razack, M., Huntley, D. (1991). Assessing transmissivity from specific capacity in a large and heterogeneous alluvial aquifer. Ground Water 29(6): 856-861.

Razack, M., Lasm, T. (2006). Geostistical estimation of the transmissivity in a highly fractured metamorphic and crystalline aquifer (Man-Danane Region, western Ivory Coast). Journal of Hydrology 325: 164-178.

Savané, I. (1997). Contribution à l'étude géologique et hydrogéologique des aquifères discontinus du socle cristallin d'Odienné (Nord-Ouest de la Côte d'lvoire). Apports de la télédétection et d'un Système d'Information Hydrogéologique à Référence Spatiale (S.I.H.R.S.). PhD Thesis, University of Cocody-Abidjan, Côte d'Ivoire, 386 p.

Savané, I., Doumouya, I., Doumbia, L. (1997). Une approche à partir de modèles statistiques pour la détermination de la productivité des puits en contexte de socle cristallin dans la région d'Odienné (Côte d'Ivoire). Hydrogéologie 4: 1926.

Soro, N. (1987). Contribution à l'étude géologique et hydrogéologique du Sud-Est de la Côte d'Ivoire. Bassin versant de la Mé. Thèse de $3^{\text {ème }}$ Cycles, University of Grenoble 1, Institut Dolomieu., France, 218 p.

Theis, C.V (1935). The relation between the lowering of the piezometric surface and the rate and discharge of a well using groundwater storage. Transactions American Geophysical Union 16 : 519-524.

Youan Ta, M. (2008). Contribution de la télédétection et des systèmes d'informations géographiques à la prospection hydrogéologique du socle précambrien d'Afrique de I'ouest: Cas de la région de Bondoukou Nord Est de la Côte d'Ivoire. PhD Thesis, University of Cocody-Abidjan (Côte d'Ivoire), 236 p.

Youan Ta, M., Lasm, T., Jourda, J.P, Kouamé, K.F, Razack, M. (2008). Cartographie structurale par imagerie satellitaire ETM+ de Landsat-7 et analyse des réseaux de fractures du socle précambrien de la région de Bondoukou (nord-est de la Côte d'Ivoire). Télédétection 2: 34-42.

Youan Ta, M., Lasm, T., Jourda, J. P., Saley, M.B., Adja, M. G., Kouamé, K., Biémi, J. (2011). Cartographie des eaux souterraines en milieu fissuré par analyse multicritère. Cas de Bondoukou (Côte d'Ivoire). Revue de Géomatique 21(1): 43-71.

Zeade, Z., Delor, C., Siméon, Y., Yao, B.D, Vidal, M., Sonnendrucker, P., Diaby, I., Cautru J.P (1995). Carte Géologique de la Côte d'Ivoire à 1/200 000 ; Feuille Bondoukou, Mémoire de la Direction des Mines et de la Géologie Abidjan Côte d'Ivoire, $\mathrm{n}^{\circ}$. 10. 